\title{
HES2 Gene
}

National Cancer Institute

\section{Source}

National Cancer Institute. HES2 Gene. NCI Thesaurus. Code C114517.

This gene is involved in the negative regulation of gene expression. 